\title{
Subduralt empyem
}
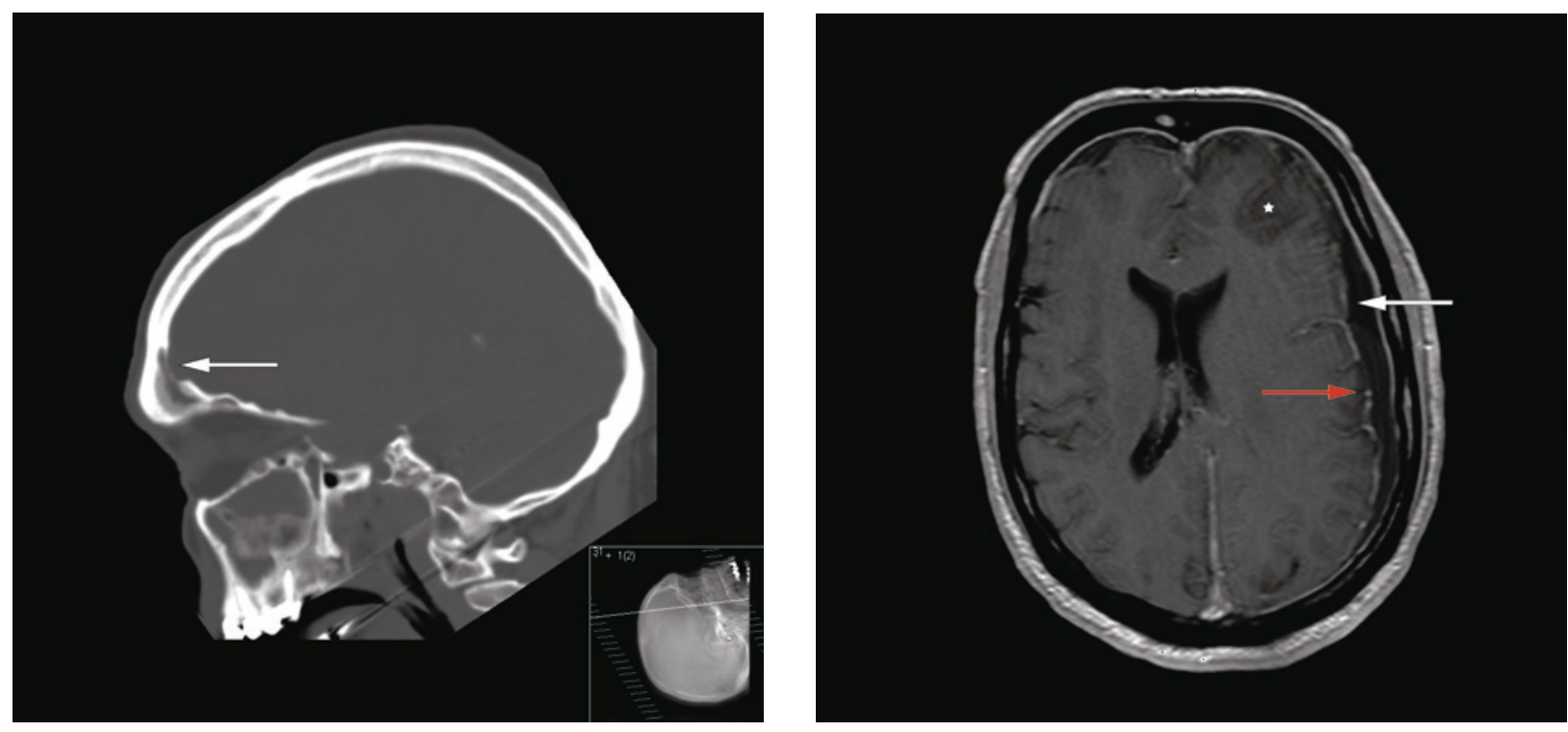

En mann i 60-årsalderen ble innlagt på lokalsykehus etter at han ble funnet konfus og med redusert bevissthet. Han hadde da ifølge komparentopplysninger hatt hodepine $i$ to dager. Ved undersøkelse var han høyfebril $\left(40,5^{\circ} \mathrm{C}\right)$ og nakkestiv. Glasgow Coma Scale ble vurdert til 12. Den nevrologiske undersøkelsen var ellers upåfallende. Cerebral CT tatt med beinvindu i sagittalplan (bilde til venstre) viste fortetning i sinus frontalis og beindefekt (pil) inn mot epiduralrommet. Cerebral MR tatt med T1-vekting etter intravenøs kontrast (bilde til høyre) viste venstresidig subdural væskeeffusjon (hvit pil), kontrastladning i dura (rød pil) og signalforandringer (stjerne) i venstre frontallapp. Spinalvæsken var blakket med hvite blodceller på $2187 \cdot 10^{6 / 1}$ (normalt $0-5$ ) og totalprotein på $1,55 \mathrm{~g} / 1$ (normalt $0,15-0,50$ ). På mistanke om subduralt empyem og cerebritt ble pasienten satt på antibiotika og overflyttet til universitetssykehus. Der ble han operert med kraniotomi og drenasje av empyem samt tetting av beindefekt i os frontale. Dyrkning av puss viste Streptococcus intermedius (Milleri).

Subduralt empyem gir ofte høy feber, hodepine, redusert bevissthet og kan gi fokalnevrologiske utfall og kramper. Det kan forårsakes av spredning av bakteriell sinusitt gjennom erosjon av beinbarrierer til epiduralrommet (1). Cerebral MR er den mest sensitive metoden for påvisning av cerebrale infeksjonssykdommer (2) og det er avgjørende at pasienter med påvist empyem eller abscess henvises raskt til kirurgisk drenasje (1).

Pasienten har gitt samtykke til at artikkelen blir publisert.

\section{Mirza Jusufovic \\ mirzajus@hotmail.com \\ Paulina Due-Tønnessen \\ Radek Fric \\ Vidar Stenset}

Mirza Jusufovic (f. 1980) er assistentlege ved Nevrologisk avdeling, Oslo universitetssykehus, Rikshospitalet.

Forfatter har fylt ut ICMJE-skjemaet og oppgir ingen interessekonflikter.

Paulina Due-Tønnessen (f. 1962) er spesialist i radiologi og europeisk godkjent nevroradiolog. Hun er seksjonsleder i Nevroradiologisk seksjon, Oslo universitetssykehus, Rikshospitalet. Forfatter har fylt ut ICMJE-skjemaet og oppgir ingen interessekonflikter.

Radek Fric (f. 1971) er spesialist i nevrokirurgi og overlege ved Seksjon for pediatrisk nevrokirurgi og Nevrokirurgisk avdeling, Oslo universitetssykehus, Rikshospitalet.

Forfatter har fylt ut ICMJE-skjemaet og oppgir ingen interessekonflikter.
Vidar Stenset (f. 1978) er lege i spesialisering i nevrokirurgi ved Nevrokirurgisk avdeling, Oslo universitetssykehus, Rikshospitalet. Forfatter har fylt ut ICMJE-skjemaet og oppgir ingen interessekonflikter.

\section{Litteratur}

1. Osborn MK, Steinberg JP. Subdural empyema and other suppurative complications of paranasal sinusitis. Lancet Infect Dis 2007; 7: $62-7$.

2. Nakstad PH, Hald JK. Nevroradiologisk magnetisk resonanstomografi -indikasjoner og bruksområder. Tidsskr Nor Lægeforen 2000; 120: 1342-6.

Mottatt 8.2. 2013, første revisjon innsendt 1.5. 2013, godkjent 13.5. 2013. Medisinsk redaktør Merete Kile Holtermann.

Engelsk oversettelse på www.tidsskriftet.no 